\title{
Rationale for Measurements to be Selected for Tractors to Perform Agricultural Activities Differing in Energy Intensity
}

\author{
Camill A. Khafizov, Ramil N. Khafizov, Azat A. Nurmiev* and Stanislav A. Sinitsky \\ Kazan State Agrarian University, Kazan, Russian Federation
}

\begin{abstract}
The topic is relevant due to the need to improve basic measurements of tractors, considering a major contribution they make to crop production, not only during separate technological operations, but also during a whole sequence of technological operations performed. The paper analyzes the limits to which the basic measurements of tractors (weight and engine power), which are used to perform a combination of technological operations requiring different energy consumption, can be altered and to identify practical limits to perform a combination of low and high energy-consuming activities. The key research method used is mathematical modeling based on system analysis and computational experiments that are carried out using models of implements during various technological operations. The results of calculations analyzed for technological operations that differ in the amount of energy consumed suggest that for each of the groups of technological operations that require similar amount of energy (soil resistivity per meter of working width, $\mathrm{kN} / \mathrm{m}$ ), there are fairly stable values of the basic measurements of tractors. A reasonable weight for tractors to perform operations such as harrowing, continuous cultivation of soil with a resistivity of 1 to $4 \mathrm{kN} / \mathrm{m}$ is $35-60 \mathrm{kN}$. For soil preparation with a resistivity of 4 to $8 \mathrm{kN} / \mathrm{m}$ it is $100-120 \mathrm{kN}$, for plowing with a resistivity from 10 to $16.25 \mathrm{kN} / \mathrm{m}$ - equal to $160 \mathrm{kN}$, for tillage with subsoilers with a resistivity from 8 to $16 \mathrm{kN} / \mathrm{m}$ - equal to $240 \mathrm{kN}$. Once put to practice, the findings will lead to a decrease in total energy consumption to $10,000 \mathrm{MJ} / \mathrm{ha}$. The amount of saved energy costs depends on the type of technological operation, the parameters of tractors used, the characteristics of agricultural implements, soil properties, etc.
\end{abstract}

\section{Introduction}

The farming system aligned with the conditions of the Republic of Tatarstan [1-9] divides farming technologies by the rate of crop production into extensive; basic (normal); intensive and high with a non-linear sequence of technological operations. Any agricultural technology includes absolutely mandatory technological operations based on the use of tractor-implement system, presently, sowing. Another group of technological operations is relatively mandatory, including soil cultivation, fertilization, etc. The last group of technological operations refers to a variable group implying techniques of plant protection, root feeding, etc. The authors here are primarily interested in a large variety of once-over tillage operations featuring in most of the listed agricultural technologies. It is here that tractors are widely used as power sources, and considerable financial and energy resources are consumed. Due to various reasons, all types of agricultural technologies mentioned are currently exploited in the agrarian sector of the Republic of Tatarstan and the Russian Federation. The extensive technologies rely on moldboard variable-depth tillage - ploughing, pre-sowing, packing, etc. The basic technologies employ soil-protecting combined, variabledepth tillage with ploughshares, cultivators, disc harrows and combined implements. Intensive technologies should be employed for differentiated minimized variable-depth tillage, alternating processing depth by crops and years. Crop cultivation operations can be conditionally classified into three groups subject to the amount of energy consumed, namely: low-input operations (harrowing, sowing on prepared soil, packing, etc. with a specific resistivity of 1 to $4 \mathrm{kN} / \mathrm{m}$ ); medium-input technological operations (shallow variable-depth tillage, sowing with combined aggregates, etc. with a resistivity of 4 to $8 \mathrm{kN} / \mathrm{m}$ ); high-input technological operations (plowing, chiseling, etc. with a resistivity of 8 to 16 $\mathrm{kN} / \mathrm{m})$.

The paper is an offshoot of a series of research towards improving technical parameters, with some of the findings to be presented in the papers [10-12].

The paper proposes some findings towards a rationale for sustainable basic measurements of tractors and implements for technological operations, classified by energy intensity, measured in $\mathrm{kN} / \mathrm{m}$ and for a combination of operations featuring in different groups. With no effective methods to address this challenge, sensitive to the parameters of tractors and tractor-

*orresponding author: azat-nurmiev@mail.ru 
implements systems that have an impact on grain crops produced, it turns from a mere production issue into a scientific problem.

\section{Materials and Methods}

The study was based on a mathematical model describing tractor-implement systems, compiled using theoretical and experimental findings, by-and-large enunciated in [9-11].

To get an idea of those impacts that machinery measurements are likely to have on yield losses, the authors reiterate the criterion for improving equipment measurements in an energy mathematical model [9].

"The criterion for improving the measurements of tractors and implements is total energy consumption per hectare of operations performed:

(1)

$$
E=E_{\text {m.t. }}+E_{\text {m.aci }}+E_{\mathrm{rm}}+E_{\text {a.d. }}+E_{\mathrm{c}}+E_{\mathrm{f}}+E_{\mathrm{agr}}+E_{\mathrm{pack}} \rightarrow m i n,
$$

where $E$ is the specific total energy consumption, $\mathrm{MJ} / \mathrm{ha} ; E_{\mathrm{m} . t .}$ and $E_{\mathrm{m} . a c i}$ is the amount of energy consumed, respectively, on the manufacture of a tractor and an agricultural implement per $1 \mathrm{ha}, \mathrm{MJ} / \mathrm{ha} ; E_{\mathrm{rm}}$ is the energy consumed for all types of repair and maintenance practices to keep a tractor and agricultural implement operational, $\mathrm{MJ} / \mathrm{ha} ; E_{\text {a.d. }}$ is the energy consumed for assembly and disassembly of a seed drill, $\mathrm{MJ} / \mathrm{ha} ; E_{\mathrm{c}}$ is the energy consumed by an operator to control a machine (turning, stopping and starting off and shifting gears), $\mathrm{MJ} / \mathrm{ha} ; E_{\mathrm{f}}$ is the energy spent on fuel consumed, $\mathrm{MJ} / \mathrm{ha} ; E_{\mathrm{agr}}$ is the energy of harvest lost due to violated agrotechnical terms for a technological operation, $\mathrm{MJ} / \mathrm{ha}$; $E_{\text {pack }}$ is the energy of harvest lost due to soil packing by tractor propellers, MJ/ha" [9].

A calculation algorithm consists in finding by a numerical method an efficient ratio of the weight of a tractor $M_{\text {opt }}$ and the power of its engine $N_{\text {opt }}$ for various groups of technological operations, depending on factors $-i$, with the condition of obtaining the minimum total energy consumption $-E$.

$$
M_{\text {opt }}=\mathrm{f}(i) ; N_{o p t}=\mathrm{f}(i) \text { if } E \rightarrow \min .
$$

Novelty and inventive step of the approach is that it is sensitive to the impacts the machinery measurements have on the volume of yields. Due to improper parameters and operating modes selected for tractors and tractor-implement systems, part of yields is lost. The longer the operation the more the crop yields lost. To eliminate this reason of crop losses, it is necessary to use high-performance implements and heavy-weight highdrawbar tractors. However, in this case soil is packed more, which leads to an increase in yield losses due to suppression of living plants, deterioration of water-air regime in the soil. Hence, it becomes possible to choose the efficient (optimal) parameters for tractors and implements [13-20]. The energy of harvest lost is up to $75-85 \%$ of the total energy consumption for technological operations performed in early spring (harrowing, cultivation, sowing, etc.), so it is simply criminal to ignore it.

The main research method is computational experiments based on mathematical models for implements performing various technological operations united into groups according to energy intensity expressed in $\mathrm{kN} / \mathrm{m}$.

Mathematical models of agricultural implements have been verified [10-11].

\section{Results}

The findings determining the efficient parameters and operating modes selected for drawbar tractor implements to perform various technological operations are partially touched upon in the papers $[10,11]$ and summarized in Table 1. Table 1 summarizes the findings by splitting technological operations into groups by energy intensity.

The results of computational experiments are shown in Fig. 1,2,3,4,5,6,7,8 in the form of graphs of changes in the parameters of the tractor and the implement, as well as the total energy consumption for technological operations differing in energy intensity, depending on specific resistance of working components of agricultural implements, expressed in $\mathrm{kN} / \mathrm{m}$. The resistance of working components turned out to have the greatest impact on the value of parameters preferred for the tractor and the TIS.

As the resistance of an agricultural implement $K$ used for all operations increases, the total energy input $E$ increases too. The working width of $B_{P}$ implements decreases or remains constant, while the optimal tractor weight $M$ and its engine power $N$ increase (sowing Fig. $1,3,4,5)$ or remain unchanged (cultivation Fig. 2). The output computation for an Agrator Ancer combine sowing system is shown in Fig. 1.

Belarus MTZ 1000 and 1200 tractors with a weight of 40 to $60 \mathrm{kN}$ and engine power of up to $120 \mathrm{~kW}$ are most suitable for the $1^{\text {st }}$ group of technological operations.

The tractors weighing from 7 to 12 tons are most efficient for the second group of technological operations. However, due to the fact that the Lemken Solitair and DMC combine seed drills are manufactured to enable a maximum working width of $12 \mathrm{~m}$, and the Agromaster and Agrator Ancer combine seed drills - 16 $\mathrm{m}$, there is a leap in optimal tractor weight from 12 to 16 tons at high values of specific resistance of seeders (high density, hardness, soil moisture, etc.) (Table 1 and Fig. 3.4.5).

In this regard, for the second group of technological operations, two brands of tractors are recommended, namely K-424 to be combined with agricultural implements enabling a working width of up to $12 \mathrm{~m}$ and K-744R-R3 for working as part of combinations with a working width of up to $16 \mathrm{~m}$.

As calculations show, the largest tractor weight (1324 tons) and its engine power (380-436 kW) are required for plowing and chiseling being the third group of technological operations. The higher the drawbar category, the more productive the tractor, the yield losses from violated agrotechnical terms for these operations decrease, and a growing negative impact of tractor propellers is compensated by deep tillage by $0.25-0.35 \mathrm{~m}$ (Table 1 and Fig. 6.7 ). 
The Kirovets K-744R-P4 tractors are recommended for plowing, while for chiseling - 9000 series tractors from various manufacturers are most preferred, including the Kirovets K-9400, New Holland-9060 or John Deere-9430.

Calculations to identify the optimal basic measurements of a tractor designed to perform both lowinput and high-input technological operations show that there are optimal measurements that largely depend on the energy intensity of a technological operation. A certain dependence of total energy consumption on the main measurements of the tractor (weight and engine power) when the tractor is exploited in sowing with a seeder resistance of $4 \mathrm{kN} / \mathrm{m}$ and plowing with a specific resistance of $70 \mathrm{kN} / \mathrm{m}^{2}$ is shown in Fig. 2. It can be seen from the graph that there is a minimum of total energy consumption for a certain combination of tractor weight $(15 \mathrm{t})$ and its engine power $(400 \mathrm{~kW})$.

Table 1. Optimal parameters of machine and tractor units in groups of technological operations, divided by their energy intensity

\begin{tabular}{|c|c|c|c|c|c|c|c|c|}
\hline $\begin{array}{l}\text { Group of } \\
\text { operations }\end{array}$ & $\begin{array}{c}\text { Technological } \\
\text { operation / Brand of } \\
\text { agricultural machine }\end{array}$ & $\begin{array}{c}\text { Unit } \\
\text { specific } \\
\text { resistance, } \\
\mathrm{kN} / \mathrm{m} \\
\end{array}$ & $\begin{array}{c}\text { Tractor } \\
\text { weight, } \mathrm{t}\end{array}$ & $\begin{array}{l}\text { Engine } \\
\text { power, } \\
\mathrm{kW}\end{array}$ & $\begin{array}{l}\text { Recommended } \\
\text { tractor brand }\end{array}$ & $\begin{array}{l}\text { Operating } \\
\text { width of the } \\
\text { unit, } m\end{array}$ & $\begin{array}{c}\text { Unit } \\
\text { operating } \\
\text { speed, } \mathrm{km} / \mathrm{h}\end{array}$ & $\begin{array}{l}\text { Total energy } \\
\text { costs, MJ/ha }\end{array}$ \\
\hline \multirow[t]{2}{*}{$\mathbf{I}$} & $\begin{array}{l}\text { Sowing on a prepared } \\
\text { surface / SZ- } 3,6\end{array}$ & $0,8-2,4$ & $2,6-6,0$ & $60-150$ & $\begin{array}{l}\text { MTZ-800- } \\
\text { MTZ-1221 }\end{array}$ & $10,8-14,4$ & 8-14 (12) & $3800-7400$ \\
\hline & $\begin{array}{l}\text { Presowing cultivation } \\
\text { / KKSh }\end{array}$ & $2,4-4,4$ & $3,5-4,2$ & $95-110$ & $\begin{array}{l}\text { MTZ-800- } \\
\text { MTZ-1221 }\end{array}$ & $5,5-6$ & $11-12$ & $2200-2800$ \\
\hline \multirow{6}{*}{ II } & $\begin{array}{l}\text { Seeding / Lemken } \\
\text { Solitair (single disc } \\
\text { opener) }\end{array}$ & $3-5$ & $7-12$ & $130-235$ & \multirow{2}{*}{$\begin{array}{c}\text { BELARUS- } \\
\text { 3022DV, } \\
\text { Kirovets K-424 }\end{array}$} & 12 & 8-14 (12) & $8800-15000$ \\
\hline & $\begin{array}{l}\text { Seeding / DMC } \\
\text { (chisel opener) }\end{array}$ & $3,2-5,2$ & $7,2-11,8$ & $154-224$ & & 12 & $8-14(12)$ & $5000-18000$ \\
\hline & $\begin{array}{l}\text { Sowing / Agromaster } \\
\text { (cultivator opener) }\end{array}$ & $3,2-5,2$ & $10,3-16,7$ & $270-410$ & \multirow{2}{*}{$\begin{array}{c}\text { Kirovets } \\
\text { K-744P1-P4 }\end{array}$} & 16 & 8-14 (12) & $5000-16500$ \\
\hline & $\begin{array}{l}\text { Sowing / Agrator } \\
\text { anker (anchor opener) }\end{array}$ & $3,2-5,2$ & $10,3-16,6$ & $265-410$ & & 16 & 8-14 (12) & $8000-14200$ \\
\hline & $\begin{array}{l}\text { Combined tillage / } \\
\text { KPIR }\end{array}$ & $4-8$ & $10-11$ & $240-292$ & \multirow{2}{*}{$\begin{array}{c}\text { BELARUS- } \\
\text { 3022DV, } \\
\text { Kirovets K-424 }\end{array}$} & $6,5-13$ & $10-11$ & $4830-9500$ \\
\hline & $\begin{array}{l}\text { Tillage with disc } \\
\text { implements / BDM }\end{array}$ & $4-8$ & $10-12$ & $272-346$ & & $7,5-12,5$ & $10,5-12$ & $4500-8900$ \\
\hline \multirow[b]{2}{*}{ III } & Plowing / PLN, PLP & $11,2-18,2$ & $13-16$ & $380-436$ & $\begin{array}{c}\text { Kirovets } \\
\text { K-744P2-P4 }\end{array}$ & $4,2-5,25$ & $10-12$ & $1600-2400$ \\
\hline & $\begin{array}{l}\text { Deep loosening of the } \\
\text { soil / PGP }\end{array}$ & $8-16$ & 24 & $382-436$ & $\begin{array}{c}\text { Kirovets K- } \\
9400 \\
\text { New Holland - } \\
\text { 9060, John } \\
\text { Deere - } 9430\end{array}$ & $6-11,5$ & $8,5-10$ & $2900-5500$ \\
\hline I - III & $\begin{array}{l}\text { Sowing SZ-3,6 + } \\
\text { plowing PLP }\end{array}$ & $\begin{array}{c}1-4 / \\
10-20\end{array}$ & $7-15$ & $220-410$ & $\begin{array}{c}\text { Kirovets } \\
\text { K- } \\
\text { 7444,P1,P2,P3 }\end{array}$ & $\begin{array}{c}10-18 / \\
3,15-4,2\end{array}$ & $\begin{array}{l}12-13 / \\
11-13\end{array}$ & $\begin{array}{l}7728,2- \\
16494,7\end{array}$ \\
\hline II - III & $\begin{array}{c}\text { Cultivation KPIR + } \\
\text { plowing PLP }\end{array}$ & $\begin{array}{c}3-6 / \\
10-20 \\
\end{array}$ & $8-19$ & $210-400$ & \multirow{2}{*}{$\begin{array}{c}\text { Kirovets K- } \\
\text { 744P2-P4, } \\
\text { New Holland - } \\
9060 \text { or John } \\
\text { Deere - } 9430\end{array}$} & $\begin{array}{c}15-18 / \\
3,85-4,2 \\
\end{array}$ & $\begin{array}{c}9 / \\
10-11 \\
\end{array}$ & $\begin{array}{l}18746,7- \\
54950,5 \\
\end{array}$ \\
\hline II - III & $\begin{array}{l}\text { Sowing Agromaster }+ \\
\text { PGP }\end{array}$ & $\begin{array}{l}3-5,4 / \\
8-16\end{array}$ & $11-19$ & $286-415$ & & $\begin{array}{l}16 / \\
5-7\end{array}$ & $\begin{array}{l}9-12 / \\
10-11\end{array}$ & $\begin{array}{l}12001,6- \\
26754,3\end{array}$ \\
\hline
\end{tabular}

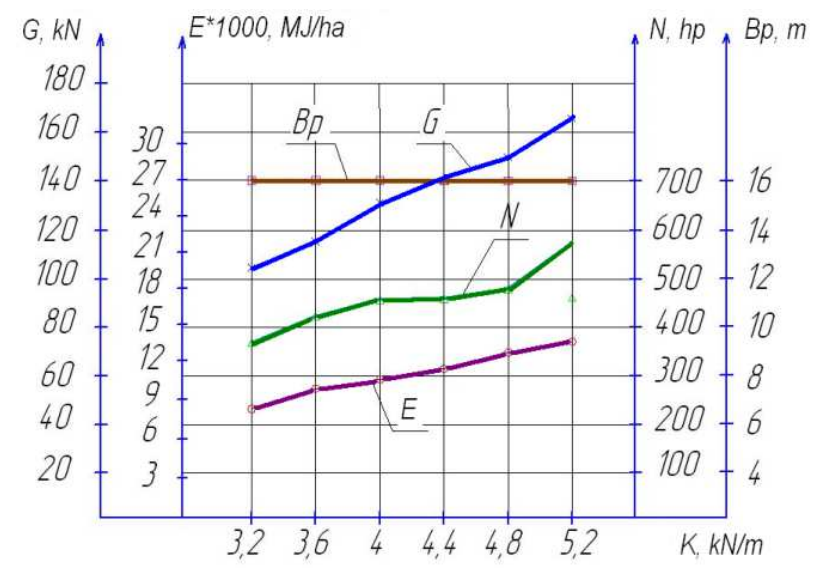

Figure 1. Influence of change in resistance of operating parts of the farm vehicle on optimum values of critical parameters of the sowing unit with the sowing Agrator Ancer system and its total energy consumption
The way the efficient (optimal) measurements of the tractor change as soon as the resistance of the seeder and the plow changes is shown in Fig. 3.

With increasing resistance of agricultural implements by $1 \mathrm{~m}$ of working width ( $K_{S}-$ seeders; $K_{P}-$ plows), the optimal values of the tractor weight $M$, the power of its engine $N$ and the total energy consumption $E$ grow. The speed of the $V_{P S}$ seeder and $V_{P P}$ plow reduces to a resistance of $K_{S}=4 \mathrm{kN} / \mathrm{m}$ and $K_{P}=70 \mathrm{kN} / \mathrm{m}^{2}$, and then increases.

The working width of the $B_{P S}$ seed drill is stable up to $K_{S}=3 \mathrm{kN} / \mathrm{m}(18 \mathrm{~m})$ and then decreases. The working width of the $B_{P P}$ plow steadily increases up to the plow resistance value $K_{P}=60 \mathrm{kN} / \mathrm{m}^{2}$, and then stabilizes around $3.85 \mathrm{~m}$. The recommended tractors for a combination of these technological operations are the Kirovets K-744R-R3 tractors.

The same calculations carried out when one tractor performs technological operations of the second and third groups show that the type of technological 
operation and their combination affects the main measurements of the tractor (Fig. 4.5).

At both combinations of technological operations, with an increase in specific resistance of agricultural implements, the weight of the tractor, its engine power and total energy consumption grow. The power stabilizes at the level of $400 \mathrm{~kW}$, weight - at the level of $190 \mathrm{kN}$. A recommended range of tractors involves Kirovets K744R2-R4, New Holland-9060 or John Deere-9430, with the last two tractors to be necessarily used with track scarifiers when they cultivate and sow. An example of a mounted track scarifier, routinely used with the tractor, with adjustable working components is shown in Fig. 6
[17]. The use of this scarifier will compensate for a negative impact that a high tractor weight has on the soil and reach maximum utilization of tractor's capacity when performing the second group of technological operations in early spring, when the risk of soil overpacking is high. The total traction resistance of the track scarifier ranges from 6 to $16 \mathrm{kN}$. It depends both on the condition of the soil and on the speed of the tractor. The harder the soil and the higher the speed of the machine, the higher the traction resistance of the scarifier. The upper limit of the recommended speed is $12 \mathrm{~km} / \mathrm{h}$.

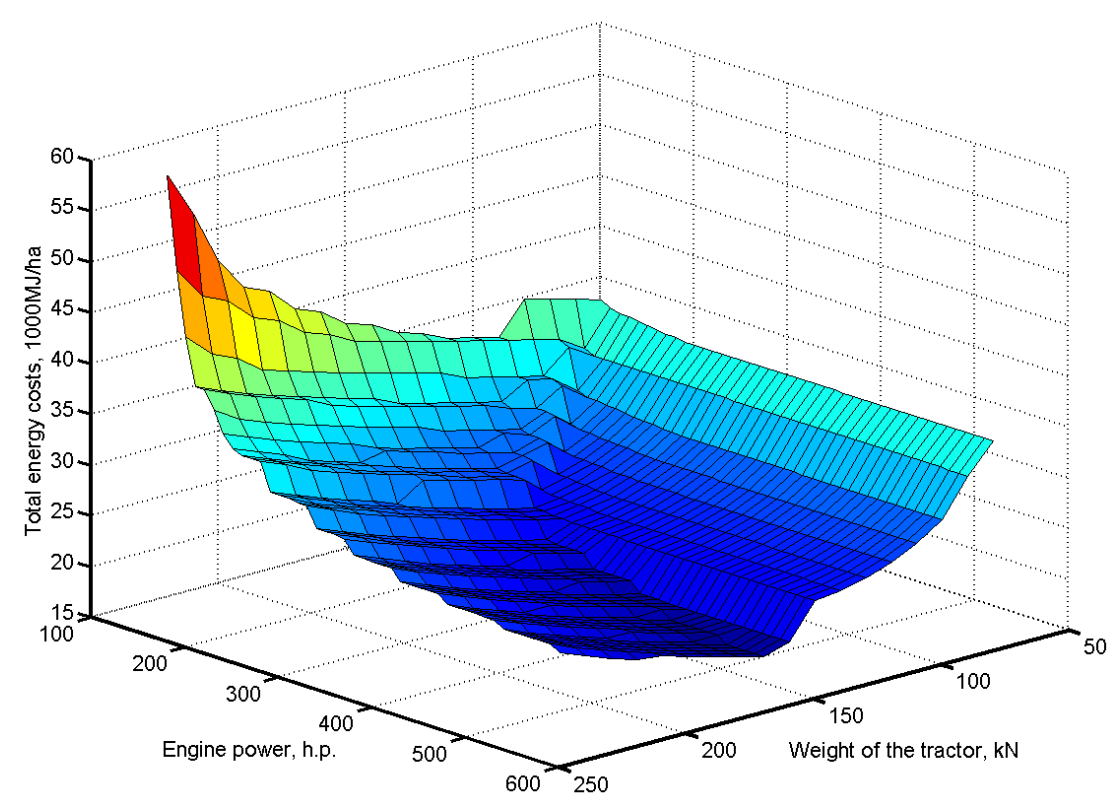

Figure 2. Changes in total energy consumption vs the main measurements of the tractor (weight and engine power) used for sowing and plowing

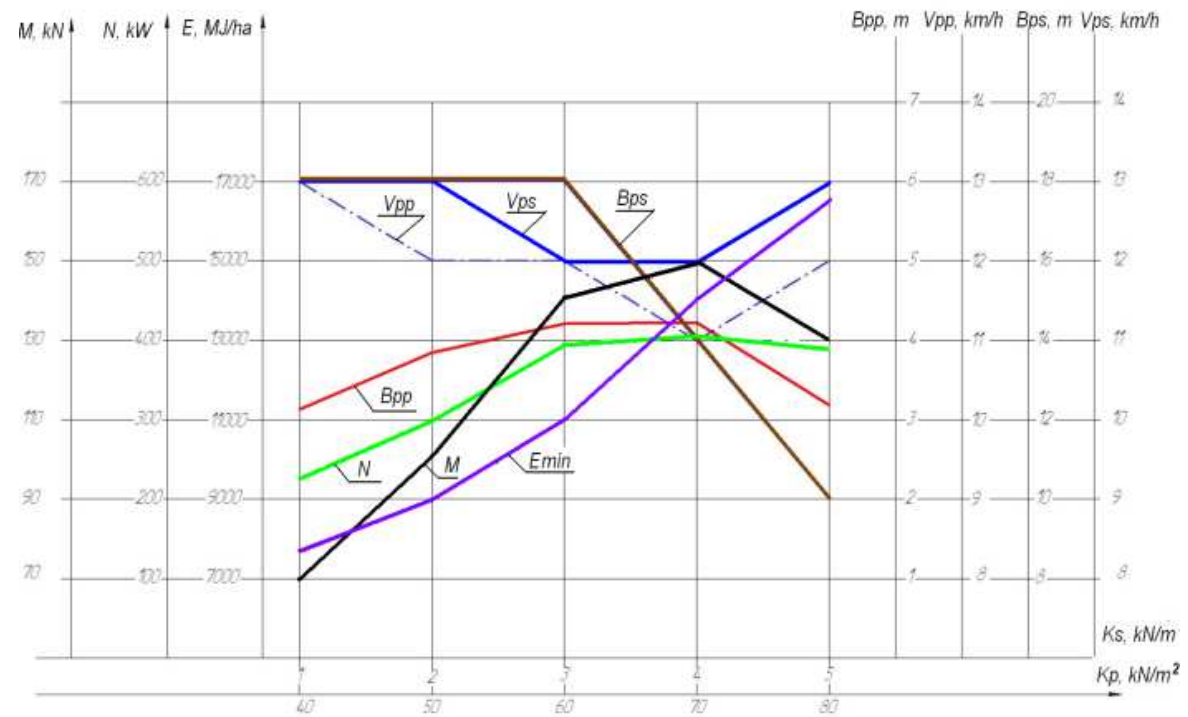

Figure 3. Changes in optimal measurements of implement assembled with standard tractor for combined sowing with SZ seeders and plowing 


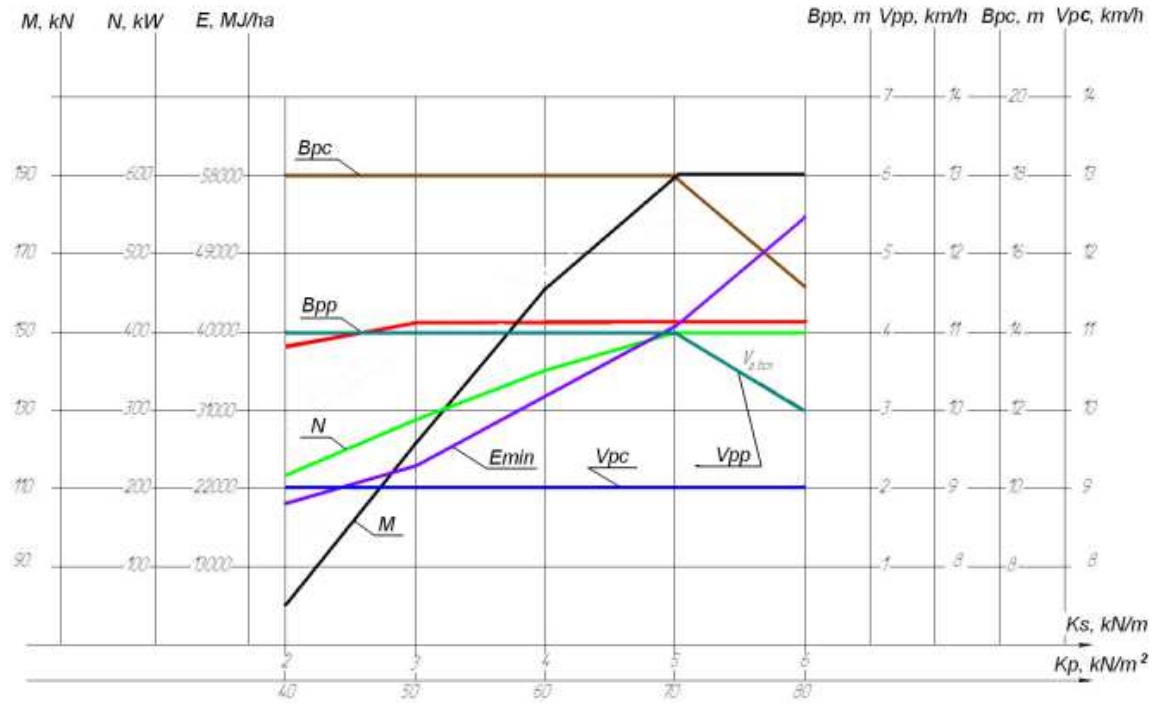

Figure 4. Changes in optimal measurements of implement assembled with standard tractor for combined cultivation with a KPIR cultivator and plowing

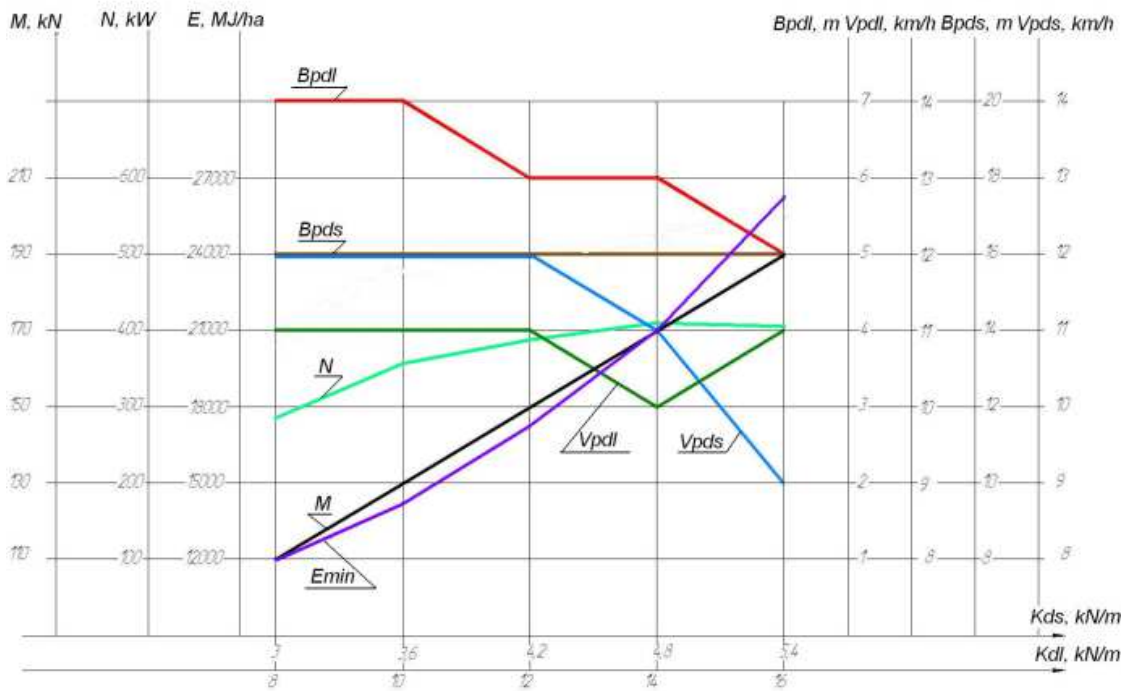

Figure 5. Changes in optimal measurements of implement assembled with standard tractor for combined direct sowing with an Agromaster seeder and chiseling

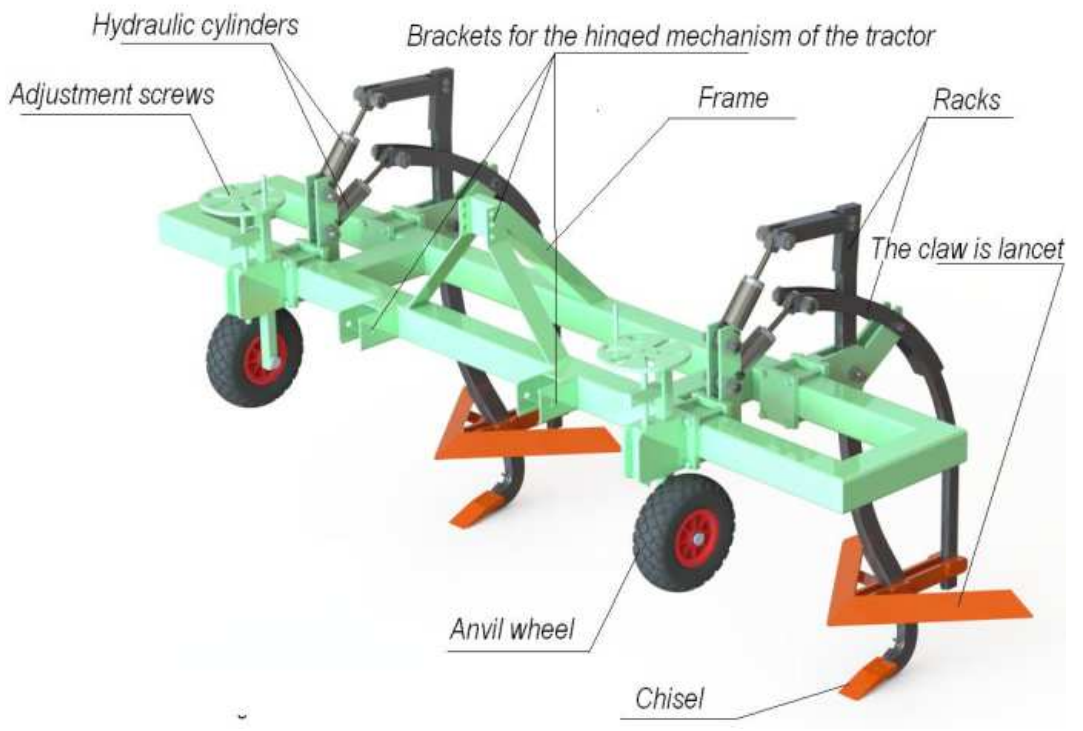

Figure 6. 3D image of a track scarifier with adjustable working tools 


\section{Conclusion}

To provide a rationale for the main measurements to be selected for the tractor and the implement, it is necessary to strive to increase the efficiency of the tractor and the implement not only by maximizing the use of engine power, increasing the tractive efficiency of the tractor, increasing the productivity of the implement, reducing operating costs, but also taking into account that the parameters of the tractor and the implement affect the yield of crops produced, which means that the parameters of the tractor must be selected with due account of the need to reduce the amount of the lost crop. The proposed criterion for improving the measurements of the tractor and the implement, the total energy consumption, allows this work to be systematic.

The proposed method for justifying the weight and power of the tractor and the measurements of the implement made it possible to reveal the efficient values of these measurements both in separate groups of technological operations and when a combination of technological operations varying in energy intensity is performed by one tractor in a single path.

The optimal weight of a tractor used in low-input operations such as harrowing, continuous soil cultivation, sowing with a specific resistance of agricultural implements from 1 to $4 \mathrm{kN} / \mathrm{m}$ is $40 \mathrm{kN}$ with a possibility of filling incremental capacity up to $50 \mathrm{kN}$ and above, engine power ranges from 60 to $120 \mathrm{~kW}$.

The second group of technological operations with a specific resistance of agricultural implements from 4 to 8 $\mathrm{kN} / \mathrm{m}$ can be made up of two subgroups, including operations using implements with a working width of up to $12 \mathrm{~m}$ and operations using implements of $16 \mathrm{~m}$ or more. To work the soil with combined implements, disc harrows and direct sowing with seeders with a working width of up to $12 \mathrm{~m}$, the optimal tractor weight is $90-100$ $\mathrm{kN}$, and the engine power is in the range of $160-300 \mathrm{~kW}$. In this case, tractor weight can be filled up to $120 \mathrm{kN}$. When utilizing wide-cutting implements with a working width of $16 \mathrm{~m}$ and more, it is advantageous to use more massive and powerful tractors with a weight of 140-150 $\mathrm{kN}$ and with an engine power of $310-400 \mathrm{~kW}$. Additional filling of the tractor weight up to $170 \mathrm{kN}$ is possible.

The third group of technological operations is represented by plowing and chiseling. For plowing, the most acceptable tractor weight is $160 \mathrm{kN}$. This weight is maintained when the resistivity of the plow changes in the range from 50 to $70 \mathrm{kN} / \mathrm{m}^{2}$. The efficient engine power ranges from 360 to $420 \mathrm{~kW}$.

When soil is cultivated with subsoilers with a traction resistance of working components from 8 to $16 \mathrm{kN} / \mathrm{m}$, the rational weight of the tractor is $240 \mathrm{kN}$ or more, and the engine power is in the range of $382-436 \mathrm{~kW}$.

To perform a combination of technological operations of the first and third groups, the tractor must have a weight of $100 \mathrm{kN}$ with a possibility of filling incremental capacity up to $140-150 \mathrm{kN}$, the engine power ranges from $220-380 \mathrm{~kW}$.

To perform a combination of technological operations of the second and third groups, the rational weight of the tractor should be $140 \mathrm{kN}$ with a possibility of filling incremental capacity on heavy soils up to 190 $\mathrm{kN}$, and the engine power should be $290-420 \mathrm{~kW}$.

Due to the fact that the optimal measurements of the tractor are influenced by many factors, including physical and mechanical properties of the soil, the features of technological operations, the speed of the operation, the design parameters of the agricultural implements and other factors, prior to establishing a machine and tractor fleet on farms, it is imperative to provide optimization calculations in order to select the most rational tractors and agricultural implements, taking into account the size of the farm fields, soil properties, cultivated crops, etc.

The recommendations proposed in the paper can be used by large agricultural enterprises in order to reduce the varieties of the machine and tractor fleet, reduce the cost of maintaining equipment in a working condition. The developed recommendations help the manufacturer reduce direct and indirect energy consumption, including the energy of the crop lost.

\section{References}

1. The farming system of the Republic of Tatarstan. Innovation based on tradition. Part 1. General aspects of agriculture (Center for Innovative Technologies, Kazan, 2013) 168 p.

2. The farming system of the Republic of Tatarstan. Part 2. Agricultural technology for the production of crops (Center for Innovative Technologies, Kazan, 2014) $292 \mathrm{p}$.

3. The farming system of the Republic of Tatarstan. Part 3. The system of organization and management of production in agriculture (agrarian management) (Center for Innovative Technologies, Kazan, 2014) $280 \mathrm{p}$.

4. N. V. Trofimov, S. R. Suleimanov, S. V. Sochneva, N. A. Loginov, Adaptive landscape farming system - the basis for land conservation in the Republic of Tatarstan, Bulletin of Kazan State Agrarian University, 13(1(48)), 69-73 (2018). DOI 10.12737 / article_5afc00e8a50138.25740490.

5. R.S. Shakirov, M. Sh. Tagirov, Increasing the efficiency of agriculture in the Republic of Tatarstan, Agriculture, 7, 9-12 (2014)

6. R. I. Safin, A. R. Valiev, R. V. Minikayev et.al, Establishment of the precision farming system in the Republic of Tatarstan, Bulletin of Kazan State Agrarian University, 5(2(16)), 153-156 (2010)

7. A.R. Valiev, R.I. Safin, N.I. Semushkin, B.G. Ziganshin, Technical support of the farming system of the Republic of Tatarstan: current state and directions of development, Bulletin of Kazan State Agrarian University, 7(4(26)), 65-70 (2012)

8. M. M. Ilyasov, A. Kh. Yapparov, N. Sh. Khisamutdinov, N. L. Sharonova, An integrated approach to the study of minimizing the cultivation of chernozem soil in the Republic of 
Tatarstan, Achievements of science and technology of AIC, 10, 22-25 (2014)

9. T.G. Khadeev, Scientific basis for increasing grain production in the Republic of Tatarstan, Agriculture, 3, 3-5 (2006)

10. K.A. Khafizov, Ways to reduce energy costs in production processes in agriculture (Kazan State University Press, 2007) 272 p.

11. C. Khafizov, R. Khafizov, A. Nurmiev, R. Usenkov, Optimization of main parameters of tractor and unit for deep processing of soil according to criterion total energy costs, in: Engineering for rural development, pp. 603-608 (2020)

12. C. Khafizov, R. Khafizov, A. Nurmiev, I. Galiev, Optimization of main parameters of tractor and unit for plowing soil, taking into account their influence on yield of grain crops, in: Engineering for rural development, pp. 585-590 (2020)

13. S. V. Shchitov, N. V. Spiridanchuk, V. F. Kuzin, Influence of the tractor traction class on the amount of energy losses from soil packing, Bulletin of KSAU, 1(76), 110-114 (2013)

14. O.V. Elkin, Application of multicriteria assessment of the use of equipment and resources at an agricultural enterprise, Siberian Herald of Agricultural Science, 5(252), 64-70 (2016)
15. A. V. Lavrov, V. A. Zubina, Methodological approaches to assessing the technological need for agricultural tractors for the agro-industrial complex, Agricultural engineering, 1(101), 20-26 (2021). DOI 10.26897 / 2687-1149-2021-1-20-26.

16. G. A. Okunev, V. L. Astafiev, N. A. Kuznetsov, Reducing the aftereffect of agricultural implements on the soil, Tractors and agricultural implements, 12, 43-47 (2016)

17. L. N. Petrova, V. K. Dridiger, E. A. Kaschaev, Effect of agricultural technologies of crop cultivation on the content of productive moisture and soil density in crop rotation, Agriculture, 5, 1618 (2015)

18. K.A. Khafizov, R.N. Khafizov, G.G. Bulgariev, Tractor track scarifier: Utility model patent RU 168668 U1 (14 February 2017)

19. Kh F. Khaliullin, I. G. Galiev, Understanding the operating conditions of vehicles when determining the standards of technical operation, Bulletin of Kazan State Agrarian University, 6(2(20)), 106-108 (2011)

20. I. G. Galiev, A. A. Mukhametshin, I. R. Iskhakov, A. R. Shamsutdinov, Improving the efficiency of using tractors in modern conditions, Bulletin of Kazan State Agrarian University, 4(2(12)), 169-172 (2009) 